\title{
Short-Rotation Coppice of Willows for the Production of Biomass in Eastern Canada
}

\author{
Werther Guidi, Frédéric E. Pitre and Michel Labrecque
}

Additional information is available at the end of the chapter

http://dx.doi.org/10.5772/51111

\section{Introduction}

The production of energy by burning biomass (i.e. bioenergy), either directly or through transformation, is one of the most promising alternative sources of sustainable energy. Contrary to fossil fuels, bioenergy does not necessarily result in a net long-term increase in atmospheric greenhouse gases, particularly when production methods take this concern into account. Converting forests, peatlands, or grasslands to production of food-crop based biofuels may release up to 400 times more $\mathrm{CO}_{2}$ than the annual greenhouse gas (GHG) reductions that these biofuels would provide by displacing fossil fuels. On the other hand, biofuels from biomass grown on degraded and abandoned agricultural lands planted with perennials do not have a negative effect on carbon emissions [1]. In addition, when properly managed, bioenergy can enhance both agricultural and rural development by increasing agricultural productivity, creating new opportunities for revenue and employment, and improving access to modern energy services in rural areas, both in developed and developing countries [2].

Biofuels constitute a very broad category of materials that can be derived from sources including municipal by-products, food crops (e.g. maize, sugar cane etc.), agricultural and forestry by-products (straws, stalks, sawdust, etc.) or from specifically-conceived fuel crops. Our analysis focuses on agricultural biofuel crops that can be grown in temperate regions. These crops can be divided into four main categories (Table 1).

Oilseed crops have long been grown in rotation with wheat and barley to produce oil for human, animal or industrial use. Today, these crops primarily provide feedstock for biodiesel. Biodiesel is produced by chemically reacting a vegetable oil with an alcohol such as methanol or ethanol, a process called transesterification. Cereals and starch crops, whose main economical use is for food and fodder, can also be transformed to produce biofuels. For example, the starch in the grains of maize (Zea mays L.), wheat (Triticum aestivum L.) and 


\begin{tabular}{|c|c|c|c|c|c|}
\hline Category & $\begin{array}{l}\text { Common } \\
\text { name }\end{array}$ & Botanical name & Habit & $\begin{array}{l}\text { Crop life } \\
\text { cycle }\end{array}$ & $\begin{array}{l}\text { Main } \\
\text { destination }\end{array}$ \\
\hline \multirow[t]{10}{*}{ Oil crops } & Camelina & $\begin{array}{l}\text { Camelina sativa (L.) } \\
\text { Crantz }\end{array}$ & \multirow[t]{10}{*}{ Herbaceous } & Annual & \multirow[t]{10}{*}{ Biodiesel } \\
\hline & Castor & Ricinus communis (L.) & & $\begin{array}{l}\text { Mostly } \\
\text { annual }\end{array}$ & \\
\hline & Field mustard & Sinapis alba (L.) & & Annual & \\
\hline & Groundnut & Arachis hypogaea (L.) & & & \\
\hline & Hemp & Cannabis sativa (L.) & & & \\
\hline & Linseed & Linum usitatissimum (L.) & & & \\
\hline & Oilseed rape & Brassica napus (L.) & & & \\
\hline & Safflower & $\begin{array}{l}\text { Carthamus tinctorius } \\
\text { (Mohler) }\end{array}$ & & & \\
\hline & Soybean & Glycine $\max$ (L.) Merr. & & & \\
\hline & Sunflower & Helianthus annuus (L.) & & & \\
\hline \multirow[t]{5}{*}{ Cereals } & Barley & Hordeum vulgare (L.) & \multirow[t]{5}{*}{ Herbaceous } & Annual & \multirow{5}{*}{$\begin{array}{l}1^{\text {st }} \text { gen. } \\
\text { ethanol / } \\
\text { Solid biofuel }\end{array}$} \\
\hline & Maize & Zea mays (L.) & & & \\
\hline & Oats & Avena sativa (L.) & & & \\
\hline & Rye & Secale cereale (L.) & & & \\
\hline & Wheat & Triticum aestivum (L.) & & & \\
\hline \multirow[t]{4}{*}{$\begin{array}{l}\text { Starch } \\
\text { crops }\end{array}$} & $\begin{array}{l}\text { Jerusalem } \\
\text { artichoke }\end{array}$ & Helianthus tuberosus (L.) & \multirow[t]{4}{*}{ Herbaceous } & Perennial & \multirow[t]{4}{*}{$\begin{array}{l}\text { 1st gen. } \\
\text { ethanol }\end{array}$} \\
\hline & Potato & Solanum tuberosum (L.) & & Annual & \\
\hline & Sugar beet & Beta vulgaris (L.) & & Biennial & \\
\hline & Sugarcane & $\begin{array}{l}\text { Saccharum officinarum } \\
\text { (L.) }\end{array}$ & & Perennial & \\
\hline \multirow[t]{7}{*}{$\begin{array}{l}\text { Dedicated } \\
\text { bioenergy } \\
\text { crops }\end{array}$} & $\begin{array}{l}\text { Kenaf } \\
\text { Sorghum }\end{array}$ & $\begin{array}{l}\text { Hibiscus cannabinus (L.) } \\
\text { Sorghum bicolor (L.) } \\
\text { Moench }\end{array}$ & Herbaceous & Annual & \multirow[t]{7}{*}{$\begin{array}{l}\text { Solid biofuel } \\
/ 2^{\text {nd }} \text { gen. } \\
\text { ethanol }\end{array}$} \\
\hline & Cardoon & Cynara cardunculus (L.) & \multirow[t]{5}{*}{ Herbaceous } & Perennial & \\
\hline & Giant reed & Arundo donax (L.) & & & \\
\hline & Miscanthus & Miscanthus spp. & & & \\
\hline & $\begin{array}{l}\text { Reed canary } \\
\text { grass }\end{array}$ & Phalaris arundinacea (L.) & & & \\
\hline & Switchgrass & Panicum virgatum (L.) & & & \\
\hline & $\begin{array}{l}\text { Short-Rotation } \\
\text { Coppice }\end{array}$ & $\begin{array}{l}\text { Eucalyptus spp. } \\
\text { Populus spp. } \\
\text { Salix spp. }\end{array}$ & Woody & Perennial & \\
\hline
\end{tabular}

Table 1. The main bioenergy crops for regions with a temperate climate. 
sorghum (Sorghum bicolor (L.) Moench) can be converted to sugars and then to ethanol by traditional fermentation methods for use in transportation and other fuels (e.g. bioethanol). These crops may also be used to produce biogas, composed principally of methane and carbon dioxide produced by anaerobic digestion of biomass. These energy crops have the advantage of being relatively easy to grow. Most are traditional agricultural crops and are easy to introduce at the farm level since they do not require particularly cutting-edge technological equipment. However, using food crops as a source of bioenergy raises serious issues related to food supply and costs, and consequently has been under increasing criticism from the scientific community and society. In particular, the use of these crops for bioenergy competes directly with their use as food. In addition, since many of these crops are annuals, they require large energy inputs and fertilizer for establishment, growth and management, and thus in the end result in minimal energy gains. For such reasons, these crops may not be efficient either for achieving energy balances or for reducing greenhouse gas emissions.

The category of dedicated energy crops notably includes all lignocellulosic (mostly perennial) crops grown specifically for their biomass and used to produce energy. Such crops include herbaceous (e.g. miscanthus, switchgrass, reed canary grass, etc.) and woody (willow, poplar, eucalyptus) species that have been selected over the past decades for their high biomass yield, high soil and climate adaptability, and high biomass quality. In addition, especially if grown on marginal arable lands, they do not compete directly for use for food [3], do not require large amounts of inputs in terms of annual cultivation and fertilizer applications [4], nor involve the destruction of native forests with severe negative effects on carbon sequestration [5] and biodiversity [6-7].

We shall limit our description to woody species, because they constitute the focus of our research.

Woody crops for energy production include several silvicultural species notably sharing the following characteristics: fast growth and high biomass yield, potential to be managed as a coppice and high management intensity (highly specific needs with regard to fertilization, irrigation, etc).

A recent review of the literature revealed that about ten different terms are used to refer to the silvicultural practice of cultivating woody crops for energy production: short-rotation woody crops, short-rotation intensive culture, short-rotation forestry, short-rotation coppice, intensive culture of forest crops, intensive plantation culture, biomass and/or bioenergy plantation culture, biofuels feedstock production system, energy forestry, short-rotation fiber production system, mini-rotation forestry, silage sycamore, wood grass [8]. The same author suggested adoption of standard terminology based on an earlier work [9] that had defined this cropping system as "a silvicultural system based upon short clear-felling cycles, generally between one and 15 years, employing intensive cultural techniques such as fertilization, irrigation and weed control, and utilizing genetically superior planting material", to which he proposed to add "and often relying on coppice regeneration", since most species used are able to sprout following harvest. The term coppice refers to a silvicultural practice in which the stem of a tree is cut back at ground level, allowing new shoots to regenerate from the stump. 
The early growth rate of coppice sprouts is much greater than that of seedlings or cuttings and in this way trees managed as coppice are characterized by remarkably fast growth and high biomass yield [10-11]. The main species under this cultivation regime in temperate climates are poplar (Populus spp) [12], willow (Salix spp) [13] and eucalyptus (Eucalyptus spp.) [14], and to a lesser extent, black locust (Robinia pseudoacacia L.) [15] and alder (Alnus spp.) [16]. All of these species, which are cultivated for biomass production in a specific region, are fast-growing under local conditions, cultivated in dense stands (to take maximum advantage of available nutrients and light, resulting in maximum growth), harvested after short rotation periods (usually between 2-8 years), and coppicable (thus reducing establishment costs). In addition, willows and poplars demonstrate ease of vegetative propagation from dormant hardwood cuttings, a broad genetic base and ease of breeding. These characteristics make them ideal for growing in biomass systems and facilitate clonal selection and ensure great environmental adaptability [17].

\section{Willow short-rotation coppice in Quebec}

\subsection{A brief history}

Scientific interest in short-rotation bioenergy willows in Canada dates back to the mid1970s' oil crisis, which stimulated the use of biomass for energy production. The Federal government's 1978 ENFOR (ENergy from the FORest) program, coordinated by the Canadian Forest Service was part of a federal interdepartmental initiative on energy research and development to promote projects in the forest bioenergy sector. Scientists from the Faculty of Forestry at the University of Toronto pioneered the investigation of willow's potential for bioenergy in Canada, convinced that willows could produce high annual yields in temperate zones [18-19] Louis Zsuffa's (1927-2003) work on selection and breeding of poplars and willows through genetic trials on small surfaces inspired the next generation of researchers, including one of his graduate students, Andrew Kenney, who implemented short-rotation intensive culture technology on the first prototype energy plantations in Canada [20]. As well, Gilles Vallée, of the Quebec ministry of Natural Resources, investigated the genetic improvement of hybrid poplar and willow with the aim of developing clones adapted to the shorter growing seasons of boreal forest locations. Our own Institut de recherche en biologie végétale (Plant Biology Research Institute), located at the Montreal Botanical Garden, grew out of the ENFOR program in the early 1990'. Our research team initially set out to identify willow species and clones well-adapted to shortrotation coppice in southern Quebec (Eastern Canada). Our experiments showed that Quebec's climate and soil are very favourable for growing various willow clones in short rotation, and that wastewater sludge can be an effective low-cost and environmentallyfriendly fertilizer [21]. Researchers from Federal and provincial ministries also initiated diverse willow projects during the 1980s and 1990s, including the genetic improvement of hybrid poplar and willow clones adapted to the short growing seasons of boreal forests [22]. Simultaneously, Natural Resources Canada, a federal ministry, collaborated with several committees, including the International Energy Agency, to improve cooperation and information exchange between countries that have national programs in bioenergy research. 
From the early 1990s to the present, dedicated, continuous research on willows in the Canadian context has been concentrated at the Montréal Botanical Garden. As a result of these extensive research efforts, approximately 300 ha of willows have been established on marginal agricultural lands in Quebec over the last 20 years.

\subsection{Site selection}

Several environmental factors can potentially influence a willow short-rotation coppice plantation and all should be evaluated prior to plantation establishment to maximize success. Ecologically, the majority of willow species are common in cold temperate regions and are adapted to mesic-hydric habitats. However, most riparian species require well-aerated substrate and flowing moisture, whereas non-riparian species have less exacting soil aeration requirements [23]. Moisture availability is an important factor determining native distribution in natural environments, successful plant establishment and high biomass yield. On average, willow coppice requires more water for growth than conventional agricultural crops [24] and consequently highly moisture retentive soil is an essential prerequisite. The lower St. Lawrence Valley, where most willow plantations in Quebec have been successfully established over the past two decades, is characterized by a temperate and humid climate with an annual average temperature of $6.4^{\circ} \mathrm{C}$, average growing season (May-October) temperature of $15.8^{\circ} \mathrm{C}$ and a mean total annual precipitation of $970 \mathrm{~mm}$. The period without freezing is on average 182 days and the total number of growing degree-days (above $5^{\circ} \mathrm{C}$ ) is 2100 .

Soil composition is another important factor for ensuring willow crop establishment and yield. In general, willow can be grown on many types of agricultural land. However, since this species is more water-dependent than other crops, particularly dry land should be avoided. On the other hand, although willow has been shown to be a rather flood-tolerant species compared to other woody energy crops [25], permanently submerged soils also constitute unsuitable sites. Ideally, willows should be grown on a medium textured soil that is aerated but still retains a good supply of moisture. Most willows grow best in loamy soils, with a $\mathrm{pH}$ ranging from $5.5-7.0$, although to a certain extent suitable soil types may range from fine sands to more compact clay soils. Several studies have shown that heavy clay soils are not very suitable for willows [26]. Most abandoned agricultural lands in Quebec are thus highly suited to growing willows, being situated in temperate regions and often adequately fertile. Other pre-establishment considerations are linked to the location of the plantation. Economical (and ecological) benefits can be maximized when high production levels of willows are achieved in combination with low input requirements, which result in high-energy efficiency and low environmental impact. For this reason, choosing the right location is crucial for achieving a sustainable energy production system. Normally, the plantation should be situated as close as possible to the end utilisation point (e.g. within 50-100 km from a power plant or transformation industry, etc.) and in any case should be established in proximity to main roads, highways or railroads. For the same reasons, the shape of willow fields should be as regular as possible to avoid loss of time and energy during management and harvest operations. For practical reasons (mainly linked to tillage and harvest) land with an elevated slope $(>15 \%)$ should be avoided. Ideal sites are flat or with a slope not exceeding $7-8 \%$. 


\subsection{Choice of planting material}

Willow yield varies greatly depending on both environmental and genetic factors. The genus Salix, to which willows belong, comprises 330 to 500 species worldwide of deciduous or, rarely, semi-evergreen trees and shrubs [27] and the number and variety of species along with the ease of breeding have facilitated clonal selection adapted to several goals (ornamental, silvicultural, environmental applications, etc.). However, a large number of willow species are not suitable for biomass production because of their slower growth rate. Nowadays, the exploitation of the wide biological diversity within the genus Salix is focused primarily on a few species (S. viminalis, S. purpurea, S. triandra, S. dasyclados, S. eriocephala, S. miyabeana, S. purpurea, S. schwerinii, and S. sachalinensis), whereas there has been a recent increase in the number of selected intra- and interspecific hybrid cultivars offering higher yields, improved disease resistance and tolerance of a higher planting density (Table 2).

In Quebec, the first trials for evaluating willow biomass potential began on small plots in the early 1990s with two species, one indigenous (S. discolor) and the other a European cultivar (S. viminalis 5027). Two growing seasons after establishment, their total aboveground biomass yield was very similar - between 15 and $20 \mathrm{t} \mathrm{ha}^{-1}$ of dry-matter per year, confirming the high potential of these two species under Quebec's agro-ecological conditions [28]. A subsequent trial aimed at evaluating these two species comparatively with S. petiolaris Smith; both the first-tested species were shown superior to the latter in terms of biomass productivity [21]. However, since after a number of years this $S$. viminalis cultivar showed sensitivity to insect attacks, particularly to the potato leaf hopper, and since the risk of epidemic diseases increases as the plantation area expands, a new set of selected clones was investigated. These experiments showed that in contrast to $S$. viminalis' poor performance due to high sensitivity to pests and diseases, other willow cultivars (S. miyabeana SX64 and S. sachalinensis SX61) could achieve high biomass yields [29]. Now, 10 years later, S. miyabeana (SX64) and S. sachalinensis (SX61) cultivars still provide the highest biomass yield and greatest growth in diameter and height among willows in the Upper St. Lawrence region. However, selected cultivars from indigenous (i.e. North-American) willow species, especially S. eriocephala (cultivars S25 and S546) and S. discolor (cultivar S 365), perform well and only slightly below SX64, thus making them preferable for use on large-scale plantations in Quebec due to their less rigorous maintenance requirements and sensitivity to insect and pest attacks.

New selected planting material has also been made extensively available by several willow growers interested in development of willow cultivation in Quebec and operating jointly with researchers. Agro Énergie (www.agroenergie.ca) was the first large-scale commercial nursery in Quebec to produce diverse varieties of willow and has continued to expand its willow plantations across Eastern Canada. For the joint project between our research team and Agro Énergie, we provide scientific expertise in terms of plantation layout, species selection, cultivation methods and management practices. The 100 hectares of land provided by Agro Énergie represent an opportunity to scale up experimental technology, perfect techniques and evaluate costs and yield, using the high performance agricultural equipment necessary for large-scale commercial production. 


\begin{tabular}{|c|c|c|c|}
\hline Taxon & English common name & Origin & $\begin{array}{l}\text { Comercial } \\
\text { varieties } \\
\text { and hybrids }\end{array}$ \\
\hline S. nigra Marshall & Black willow & North America & $\mathrm{S} 05^{*}$ \\
\hline S. triandra $\mathrm{L}$. & Almond-leaved willow & Eurasia & $\begin{array}{l}\text { Noir de Villaines+, } \\
\text { P6010+, }\end{array}$ \\
\hline S. alba L. & White willow & $\begin{array}{l}\text { Europe, Africa, } \\
\text { \& west Asia }\end{array}$ & $\mathrm{S} 44^{*}$ \\
\hline S. eriocephala Michx. & Heart-leaved willow & North America & $\mathrm{S} 25^{*}, \mathrm{~S} 546^{*}$ \\
\hline S. discolor Muhl. & American pussy willow & North America & $\mathrm{S} 365^{* ¥}$ \\
\hline S. dasyclados Wimm. & $\begin{array}{l}\text { Wooly-stemmed } \\
\text { willow }\end{array}$ & Eurasia & $S V 1^{* *}$ \\
\hline S. schwerinii Wolf & Schwerin willow & East Asia & \\
\hline $\begin{array}{l}\text { S. udensis ( } \sin \text { S. } \\
\text { sachalinensis)Trautv. }\end{array}$ & & East Asia & SX61* \\
\hline S. viminalis $\mathrm{L}$. & $\begin{array}{l}\text { Common osier or } \\
\text { basket willow }\end{array}$ & Eurasia & $\begin{array}{l}\mathrm{SVQ}^{*}, \mathrm{~S}^{*} 3^{*}, 5027^{*} \\
\text { Jorr }^{+}\end{array}$ \\
\hline S. miyabeana Seemen & Miyabe willow & East Asia & SX64*, SX67* \\
\hline S. purpurea L. & $\begin{array}{l}\text { Purple willow or } \\
\text { purple osier }\end{array}$ & $\begin{array}{l}\text { Northern Africa } \\
\text { \& Europe }\end{array}$ & Fish Creek ${ }^{*}$ \\
\hline S. acutifolia Willd. & Pointed-leaf willow & Eastern Europe & S54* \\
\hline $\begin{array}{l}\text { S. sachalinensis } \times S \text {. } \\
\text { miyabeana }\end{array}$ & & & $\begin{array}{l}\text { Sherburne*, } \\
\text { Canastota* }\end{array}$ \\
\hline S. purpurea $\times$ S. miyabeana & & & Millbrook* \\
\hline $\begin{array}{l}\text { S. eriocephala } x \text { S. interior } \\
\text { S. viminalis } x \text { S. schwerinii }\end{array}$ & & & $\begin{array}{l}\text { S625* } \\
\text { Bjorn }^{+}, \text {Tora }^{+}, \\
\text {Torhild }^{+}, \text {Sven }^{+}, \text {Olof }^{+}\end{array}$ \\
\hline
\end{tabular}

Table 2. Most common Salix taxa and corresponding commercial varieties for biofuel production in Quebec (* Selected in North America; ${ }^{+}$Selected in Europe; ${ }^{*}$ Its identity is currently under study). 


\subsection{Land preparation and weed control}

Appropriate soil preparation is essential to ensure good plant establishment and vigorous growth. This is particularly true when willows are to be established on soil with low fertility or marginal land. The main goal of any land preparation operation should be to eliminate weeds, aerate soil and create a uniform soil surface for planting. Once the planting site has been chosen, the first operation to be performed is preparation of the land much as for any other agricultural crop. The productivity of trees under short-rotation intensive culture is strongly influenced by herbaceous competition. One of the first trials conducted by our research team in the early 1990s showed that weed suppression was essential to willow establishment [30]. On Quebec's generally well-drained lands, the most common weeds are broad-leaved annuals such as white goosefoot (Chenopudium album L.) and redroot pig-weed (Amaranthus retroflexus L.), whereas on poorly drained lands, annual grasses, barnyard grass (Echinochloa crusgalli L.) and perennials such as Canada thistle (Cirsium arvense L.) and quack grass (Agropyron repens (L.) Beauv.) are more common [30]. In the case of abandoned agricultural lands or in the presence of a high concentration of weeds, one or two applications of a systemic herbicide (e.g. glyphosate 2- $4 \mathrm{~L} / \mathrm{ha}$ ) during the summer of the year prior to planting are strongly recommended to promote establishment. A few weeks later, the destroyed plant mass should be incorporated into the soil using a rotating plough. In Quebec, a first ploughing should be performed in the fall prior to planting. Autumn ploughing allows the soil to break down over the winter, and also increases the amount of moisture in the planting bed. Suitable equipment includes any common mouldboard, chisel or disc plough $(20-30 \mathrm{~cm}$ depth), following usual agronomical practices for other crops (e.g. maize). Power harrowing (15- $18 \mathrm{~cm}$ depth) or cross disking of the site should be carried out in the spring immediately prior to planting to ensure a flat, regular planting bed.

\subsection{Plantation design and planting}

Willows can be planted according to two different layouts. In most North European countries (Sweden, UK, Denmark) and in the US, the most frequent planting scheme is the double row design with $0.75 \mathrm{~m}$ distance between the double rows and $1.5 \mathrm{~m}$ to the next double row, and a distance between plants ranging from $1 \mathrm{~m}$ to $0.4 \mathrm{~m}$, corresponding to an initial planting density of 10,000 - 25,000 plants ha ${ }^{-1}$. The most common plantation density in these countries is currently around $15,000(1.5 \times 0.75 \times 0.59 \mathrm{~m})$ plants ha ${ }^{-1}$ [31]. This rectangular planting arrangement is used to facilitate field machine manoeuvres through the plantation site. Tractors overlap the double row and the wheels run in the wider strips between those rows [32]. In Quebec, a simpler willow planting design, similar to that used for poplar in short rotations, has been in use since initial trials with only minimal modifications. It consists of a single row design ranging from $0.33 \mathrm{~m}$ between plants on a row and $1.5 \mathrm{~m}$ between rows $(20,000$ plants ha-1) in the very first plantations, to $0.30 \mathrm{~m}$ on the row and $1.80 \mathrm{~m}$ between rows $\left(18,000\right.$ plants ha $\left.^{-1}\right)$ in newer willow plantations. Theoretically, this design facilitates weed control during the establishment phase (the first three years), and consequently willow rooting and growth. In fact, the design choice depends mostly on machinery available for planting and harvesting, since it has been clearly 
demonstrated that planting design has less impact than plant density and cutting cycle on the yield of Salix plants, due to their ability to take advantage of the space available to each stool [32]. The choice of planting density must take into account other ecological factors as well. On sites with appropriate water supply, plantation establishment and subsequent biomass production depend largely on agronomic considerations such as plant spacing and harvesting cycles. Many studies have reported a correlation between spacing and harvesting cycles. In general, maximum yields are achieved early in dense willow plantations, but wider-spaced plantations ensure the highest long-term biomass yield [33-34]. On the other hand, under short harvesting cycles, willow stands have a shorter duration, as they are likely to be more exposed to pathogens [35]. At present, most willow short-rotation stands in Quebec have a plantation density of about 16,000 to 17,000 cuttings ha ${ }^{-1}$ and are harvested every two to three years.

Planting material consists of dormant willow stem sections, either rods or cuttings, depending on the planting machinery to be adopted. In some countries, for example in the UK and in the USA, 'step planters' are the most commonly used machines. Willow rods 1.5$2.5 \mathrm{~m}$ long are fed into the planter by two or more operators, depending on the number of rows being planted. The machine cuts the rods into $18-20 \mathrm{~cm}$ lengths, inserts these cuttings vertically into the soil and firms the soil around each cutting. Step planters have been calculated to cover $0.6 \mathrm{ha} / \mathrm{hr}$ in a UK study. [31]. In Quebec, the most common planting machine is a cutting planter that uses woody cuttings $(20-25 \mathrm{~cm}$ long) and may operate on 3 rows simultaneously (Figure 1).

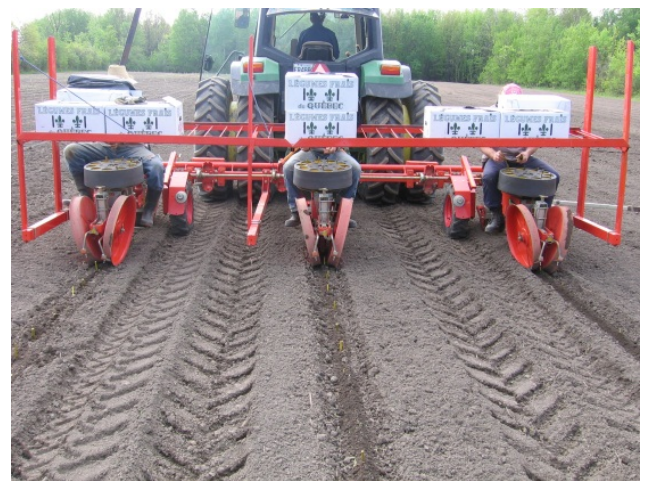

Figure 1. Willow planting machine operating on 3 rows simultaneously

Normally, a cutting planter inserts cuttings into the soil at a depth of about $18 \mathrm{~cm}$. Based on empirical experience, this equipment can plant 3,600-4,000 cuttings per hour (1 ha of willow every 3-4 hours), although the duration of this operation may vary depending on several factors (site topography, soil type, plot shape, etc.). Planting material in Quebec is prepared by harvesting one-year-old stems (about $3 \mathrm{~m}$ long) in the autumn (i.e. when plants are dormant) of the year prior to planting. This material is wrapped in plastic film to avoid moisture loss, and stored in a refrigerator at -2 to $-4^{\circ} \mathrm{C}$. In spring, two to three weeks prior to planting, healthy willow rods $1-2 \mathrm{~cm}$ in diameter (with no symptoms of disease on bark or 
wood) are selected to prepare cuttings. Tips of stems bearing flower buds are first discarded. Then the rest of the whip is cut into 20-25 cm lengths using an adapted rotary saw and stored in boxes, ready to be planted (Figure 2).

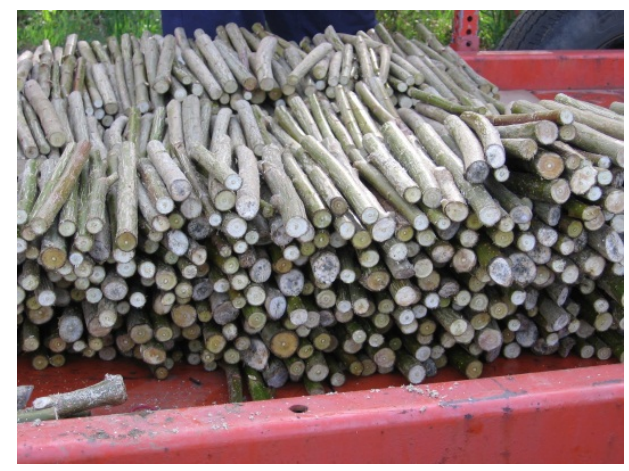

Figure 2. Willow cuttings before planting

If cuttings are left in temperatures above $0^{\circ} \mathrm{C}$, a break in their dormancy will occur, adventitious roots will develop and the buds may burst. This will lead to a reduction in water and nutrient content and consequently reduced viability. Thus, it is very important to plan the planting operation carefully in advance, calculating the number of cuttings that can be planted.

The time of planting varies according to meteorological and soil conditions. Planting should be undertaken as soon as possible in the spring, to allow plants to benefit from the high soil water content following snowmelt, and then to establish quickly and take maximum advantage of a long growing season. In addition, a late willow planting is also more subject to failure due to drought if a dry summer should occur. However, there are several additional factors that play an important role in determining the planting date. In order for soil preparation (e.g. harrowing) to begin in the spring, soil should be free from snow but not so muddy that soil structure could easily be damaged by tractors. The date at which such conditions are met vary considerably from year to year, but in southern Quebec, it usually falls during May, although late planting (up to mid-June) is possible and, in our experience, does not result in serious problems in plant establishment. Planting willow in the colder, northernmost regions of Quebec (e.g. Abitibi) may take place up to the beginning of July. In all of these situations, rapid colonisation by highly competitive weed species occurs on fertile sites, thus the use of appropriate residual herbicides is essential to maximize plant survival and early growth. Pre-emergence residual herbicide should be applied immediately upon completion of planting (within a maximum delay of 3-5 days). A mixture of two herbicides (2.30 kg Devrinol and $0.37 \mathrm{~kg}$ Simazine per hectare) has been effective on most of our plantations. Since the treatment must reach the zone of weed seed germination, most pre-emergence herbicides require mechanical incorporation (such as by a power tiller) as well as adequate irrigation or natural moisture (rainfall or snow) for best results. More recently, a new herbicde (SureGuard, a.i. flumioxazin) has received approval 
for pre-emergent use at the time of planting on poplar and willow (including planting stock production in the field, on both stoolbeds and bareroot beds).

\subsection{Crop management}

\subsubsection{Establishment year}

All operations carried out in a willow stand during the first year are aimed at promoting plant establishment and a high survival rate, thereby ensuring the on-going productive life of the plantation. Weeds are the main problem encountered in willow crop, and they may still colonise fields despite pre-emergence treatments. It was established decades ago that during the first year after planting, vigorous weeds reduce willow growth by between $50 \%$ and $90 \%$ [36]. Most of these invasive species have higher growth rates than young willow shoots, and compete with them mainly for light [37], and to a lesser extent for water and nutriments, leading to high plant mortality within the first few months. Hence, great care should be taken to control weed development in the field in the weeks following planting. On most willow plantations in Quebec, one to three passes with a rotary tiller cultivator between rows are needed to control weeds during the establishment year. In case of a severe weed problem, manual weeding may be required between plants within each row.

\subsubsection{Cutback}

There is much evidence that most newly-established willow plantations profit immensely from being cut back at the end of the first growing season (Figure 3).

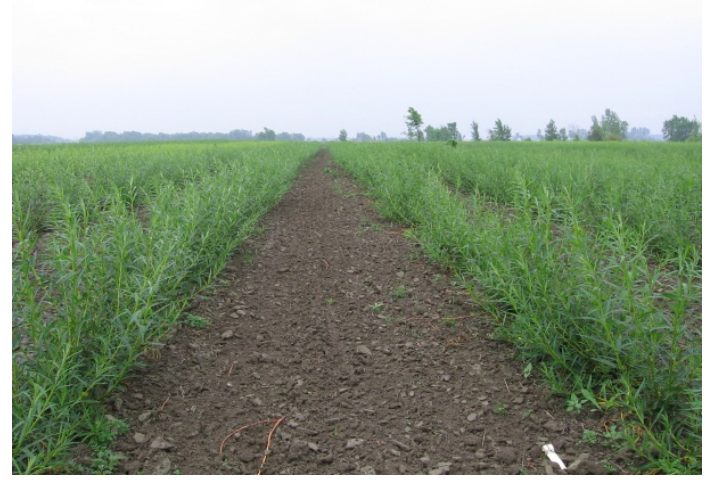

Figure 3. After cutback willows sprout vigorously from the stumps

Not only does cutback encourage established cuttings to produce vigorous multiple shoots the following spring, it also helps reduce competition by weeds, thereby reducing the need for continued chemical weed control [38]. Furthermore, cutback facilitates entering the field at the beginning of the second growing season to fertilize and till soil between rows. Cutback is normally performed in the fall by cutting all newly-formed shoots at ground 
level using conventional agricultural equipment, such as reciprocating mowers for large surfaces or a trimmer/brush-cutter for small plots.

\subsubsection{Fertilization}

For many reasons, fertilization is a controversial aspect of short-rotation plantation, subject to fluctuations in practice. Our review of the historical evolution of willow short-rotation forestry in different countries suggests that the initially highly favourable attitude toward using chemical fertilizers has tended to attenuate over time, mainly because other issues beyond the biomass yield (both economical and environmental) have arisen. Different perspectives on this topic have also arisen out of legislation that in some countries has favored more environmental-friendly management (e.g. by reducing mineral fertilization and enhancing the application of biosolids and waste materials) of bioenergy cropping systems.

However, it is an irremediable fact that, due to high biomass yields, most willow energy crops grown in short-rotation and intensively managed and harvested remove nutrients at a high rate, though evidence varies somewhat (Table 3).

\begin{tabular}{llllll}
\hline \multicolumn{7}{l}{ Annual nutrient removal $\left(\mathrm{kg} \mathrm{tDM}^{-1}\right)$} & & & \\
\cline { 1 - 5 } $\mathrm{N}$ & $\mathrm{P}$ & $\mathrm{K}$ & $\mathrm{Ca}$ & $\mathrm{Mg}$ & Reference \\
\hline 20.6 & 6.9 & 13.7 & - & - & {$[39]$} \\
13.6 & 1.5 & 8.5 & - & - & {$[40]$} \\
13.0 & 1.6 & 8.3 & - & - & \\
6.3 & 1.0 & 7.5 & - & - & {$[41]$} \\
5.7 & 1.0 & 3.0 & 3.0 & 1.0 & {$[42]$} \\
5.3 & 0.9 & 3 & 7.2 & 0.7 & \\
7.5 & 0.6 & 1.8 & 4.2 & 0.4 & {$[43]$} \\
5.0 & 0.7 & 1.8 & 3.5 & 0.3 & \\
3.9 & 0.5 & 1.5 & 3.6 & 0.2 & {$[44]$} \\
3.5 & 0.5 & 2.5 & - & - & {$[45]$} \\
\hline
\end{tabular}

Table 3. Average mass of nutrient removal $(\mathrm{kg})$ per oven dry ton of aboveground willow biomass

Some authors have highlighted that $\mathrm{N}$ fertilization in willow plantations at the beginning of the cutting-cycle, excluding the year of planting, is generally a very efficient way to enhance plant growth [45-46]. On the other hand, willow nutrient requirements are relatively low, due to efficient recycling of $\mathrm{N}$ from litter and the relatively low nutrient content retained in biomass (stem). Therefore, much less nitrogen fertilizer should be applied than is typical with agricultural crops, although dosage should also be based on formal soil chemical analyses performed prior to plant establishment. Several authors have indicated that no nitrogen is required in the planting year for short-rotation coppice [39-47]. This also reduces the competitiveness of weeds that would take advantage of fertilizer application. Economical considerations are yet another factor to consider when determining the dose of fertilizer to be used, since fertilizer constitutes a significant percentage of the financial cost involved in the production of willow biomass crops. A recent study conducted in New York 
State showed that fertilizer represents up to $10-20 \%$ of the cost of production over several rotations [48]. The average dose generally recommended in Quebec ranges from the equivalent of $100-150 \mathrm{~kg} \mathrm{~N}, 15 \mathrm{~kg}-40 \mathrm{~kg}$ P and around $40 \mathrm{~kg} \mathrm{~K}$ per hectare per year after the establishment year. Because it is not possible to introduce heavy equipment into the field after plantation establishment, fertilizer application is normally performed one year after planting and after any harvest, when tractors can circulate freely in the field.

An interesting alternative to mineral fertilizers are biosolids and other industrial and agricultural byproducts, which have been tested in many countries since the early 1990s. These include municipal wastewater [49], wastewater from the dairy industry, landfill leachate [50], diverted human urine [51], industrial wastewaters such as log-yard runoff [52], as well as solid wastes like digested or granulated sludge [53] and pig slurry [54]. In fact, the majority of these products contain high levels of nitrogen and phosphorous, elements that might constitute a source of pollution for the environment but at the same time represent a source of nutrients for the plant. Thus there are many advantages to using such products in willow plantations:

1. recycling of nutrients, thereby reducing the need for farmers to invest in chemical fertilizer;

2. conservation of water;

3. prevention of river pollution, canals and other surface water, into which wastewater and sewage sludge would otherwise be discharged;

4. low-cost, hygienic disposal of municipal wastewater and sludge.

Willow cultivated in short rotation is a very suitable crop for fertilization with these products for several reasons. First, it has been determined, both by measured and estimated models, that this crop has high evapotranspiration rates and thereby consumes water quantities as high as any other vegetation cover, which allows significant wastewater disposal over each growing season [24-55-56]. Furthermore, willow short-rotation stands have been shown to be able to uptake large amounts of nutrients present in this waste [57]. Last but not least, willow coppice is a no food no fodder crop and, if properly handled, any possible source of human or environmental contamination is strongly reduced [58]. In some early trials carried out in Quebec to test the possibility of using sludge in willow shortrotation culture, it was found that a moderate dose of dried and palletized sludge (100-150 $\mathrm{kg}$ of "available" $\mathrm{N}$ ha $^{-1}$ ) might constitute a good fertilizer during the establishment of willows, especially on clay sites [53-59]. Today, the recommended dose of derived wastewater sludge fertilizer in Quebec ranges between 18-21 t ha-1 of dried material, which corresponds to $100-120 \mathrm{~kg}$ available nitrogen per hectare. Fertilization is performed in spring of the second year after planting with ordinary manure spreading machines. Another recent project investigated the effect of the use of pig slurry as fertilizer on the productivity of willow in short-rotation coppice (Figure 4).

The results showed that pig slurry is good fertilizer for willow plantations [54]. In fact, very high biomass yields were obtained over two years, and even made it possible to predict that typical three-year rotation cycles could be reduced to two years, under the proper 


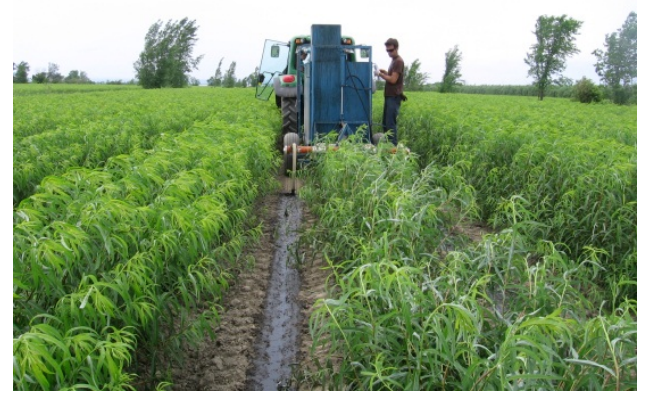

Figure 4. Pig slurry application to a willow plantation

production conditions. This means that even though nitrogen in slurry may be less efficient than that in a mineral fertilizer, a significant reduction in the production costs of willowbased biomass as well as recycling of a greater quantity of slurry can be achieved simultaneously [54].

\subsection{Pests and diseases}

Although there are a great number of insects feeding on willows, three main species are of concerns for willow short rotation coppice in Quebec. The first is the willow leaf beetle (Plagiodera versicolora Laicharteg.), one of the most common insects found on willows. The willow leaf beetle is a small (4-6 mm long), metallic-blue beetle widely distributed around the world. In Quebec, adults emerge from their overwintering quarters under the loose bark and feed on young willow foliage in spring. Egg laying begins in mid-June. Females lay yellow eggs grouped on the undersides of the leaves. The young larvae emerge a few days later and begin feeding on both sides of the leaves and eating the tissue between the veins, thus skeletonizing the leaves and, depending on the extent of the attack, in all probability leading to a reduction of plant growth. In Quebec, this insect has been frequently observed feeding on leaves of clones of Salix viminalis and to a much lesser extent on most common commercial varieties of S. miyabeana (SX64 and SX67) and S. sachalinensis (SX61). To date, the reported threshold of damage caused by this insect has never been high enough to justify any type of control. However, in case of severe attack, non-toxic products based on Bacillus thuringiensis, shown to be effective in eliminating this pathogen, can be used [60].

The other predominant insects found feeding on willow trees and shrubs are two aphid species: the giant willow aphid, Tuberolachnus salignus (Gmelin) and the black willow aphid, Pterocomma salicis (L) [61].

The giant willow aphid. is one of the largest aphids ever recorded, measuring up to 5.8 $\mathrm{mm}$ in length [62]. It feeds almost exclusively on willow, but has very occasionally been recorded on poplar (Populus spp.). The species is strongly aggregative, forming vast colonies on infested trees. These colonies can cover a significant portion of the 1-3 year old 
stem surface of a willow tree. Laboratory experiments with willows grown in soil and in hydroponic culture have revealed that this species can reduce the above-ground yield of biomass willows, have severe negative effects on the roots and reduce the survival of both newly planted and established trees [63]. Other preliminary studies carried out in the UK have shown that this insect's feeding behavior is affected by chemical cues from the host. Researchers found that one of its most preferred willows was S. viminalis [64]. Although large colonies of this insect have recently been found on several willow varieties in Quebec, it is not yet possible to estimate its threat to willow plantations in this region (Figure 5).

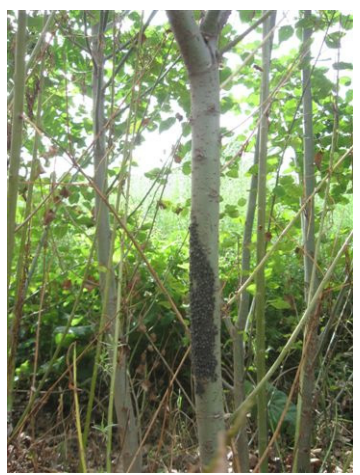

Figure 5. Giant aphids feeding on willow. This insect is often found forming large colonies at base of the stem.

The black willow aphid, Pterocomma salicis (L) may actually pose a threat only if severe, frequent attacks occur. Several studies have shown that this species is less damaging than the giant willow aphid, with a less persistent negative impact on willow growth. In Quebec, high density populations of this species have recently been found at the end of June on a willow plantation in the upper St. Lawrence River valley (Huntingdon), mainly on $S$. miyabeana (SX67 and SX64); it did not seem to feed on S. viminalis.

Other less damaging insects have been found on willow plantations in Quebec. Calligrapha multipunctata bigsbyana adults and larvae may feed on willow leaves without destroying leaf veins, with consequences quite similar to those of Plagiodera versicolora. Willow flea beetles of the genus Crepidodera (C. nana and C. decoraalso feed on Salicaceae leaves [65], and are easy to recognize by their brilliant metallic and bicoloured upper surface; blue or green head and pronotum tinged with strong bronze, copper or violet; and unicolorous blue or green elytra. This beetle feeds on either the upper or lower leaf surface, consuming the epidermis and tissue below, but not on the opposite side. After desiccating, the tissue falls out, resulting in a leaf with a bullet-hole appearance. Varieties of willows developed in Europe, based on pedigrees with Salix viminalis or S. viminalis $\mathrm{x}$ S. schwerinii, are susceptible to potato leafhopper (Empoasca fabae Harris), which causes serious damage to this species and its cultivars or hybrids. Willow shoot sawfly (Janus abbreviates Say) larvae have recently been found in Quebec, carving deep tunnels on young willow S. miyabeana SX64 shoots where 
they cause wilting, change of colour (brown or black) and eventually drooping of shoot tips. It has been observed that in some cases 30\% of individuals of SX64 in Huntingdon showed at least one shoot affected by this insect. However, only repeated and severe attacks in young willow plantations may adversely affect tree growth.

Willow can be injured by several diseases [66]. Willow leaves may be sensitive to Alternaria spp., Melamsora spp. and Venturia spp., whereas Cryptodiaporthe spp., Glomerella spp. and Valsa spp. are found to affect stems and branches and Armillaria spp., Fusarium spp. and Verticilium spp. roots [67]. However, the most widespread, frequent and damaging disease in willow plantations is leaf rust, caused by Melampsora spp. In northern Europe, leaf rust is considered a major factor limiting growth of short-rotation coppice willow [68]. It can cause premature defoliation, poor cold acclimation, premature leaf senescence, and a predisposition to abiotic stress (e.g., competition and drought) in host trees, along with secondary disease organisms, and it may reduce yields by as much as $40 \%$ [69]. One of the main alternative solutions to spraying fungicides proposed in northern Europe is growing willow in inter- and intra-species mixtures [70]. If a variety dies out of a mixture due to disease, competition or some other factor, the remaining varieties can compensate for the loss [71]. In some willow plantations in Quebec, severe attacks of Melamsora spp. have been detected mainly on a specific commercial clone S301 (S. interior $62 \times$ S. eriocepala 276), which seemed to be more vulnerable to rust than any other clone studied in the area [29]. Few rust attacks have been reported for most commercial clones, however, chemical or biological disease control is generally not required.

\subsection{Harvesting and yields}

Willow should be harvested at the end of each rotation cycle (2-5 years), normally in fall, after leaf shedding. All willow stems should be cut at a height of $5-10 \mathrm{~cm}$ above the soil surface in order to leave a stump from which new buds will form sprouts the following spring. Essentially, there are three ways to harvest willows, the choice largely depending on the final destination of biomass and the equipment available. When willows are grown to produce rods to be used in environmental engineering structures such as sound barriers, snow fences and wind breaks along highways and streets [72-73] or to produce new cuttings, plants are harvested with trimmer brush-cutters. Whole willow rods can also be stored in heaps at the edge of the field and chipped after drying.

Another option involves the use of direct-chip harvesting machines (e.g. Class Jaguar and Austoft). This technique uses modified forage harvesters specifically designed to harvest and direct chip willow stems: the stems are cut, chipped and dropped into a trailer either driven parallel to the harvester or connected directly to it. Although this harvest model is very economically efficient and recommended in many countries, it also presents several disadvantages that should be carefully evaluated. Willow biomass has a moisture content of $50-55 \%$ (wet basis) at harvest. Consequently, storage and drying of the freshly chipped wood may cause problems. It has been shown that stored, fresh wood chip in piles can heat up to $60^{\circ} \mathrm{C}$ within 24 hours and start to decompose. Biomass piles require careful 
management because internal fermentation can cause combustion and the high level of fungi spore production can lead to health problems for operators. Decomposition processes cause a loss of biomass of up to $20 \%$ and a significant reduction in calorific value (i.e. energy value) of the biomass [74]. Thus, this type of harvest system requires infrastructures to mechanically dry the biomass (e.g. ventilation, heating, mixing machinery) and these postharvest operations increase the production cost. Alternatively, the freshly chipped material should be delivered to heating plants as soon as possible.

A third harvest system recently developed in Canada, mainly adapted to willow shortrotation coppice, is a cutter-shredder-baler machine that performs light shredding and bales willow stems [22], producing up to 40 bales hr-1 $^{-1}\left(20 \mathrm{t} \mathrm{hr}^{-1}\right)$ on willow plantations (Figure 6).
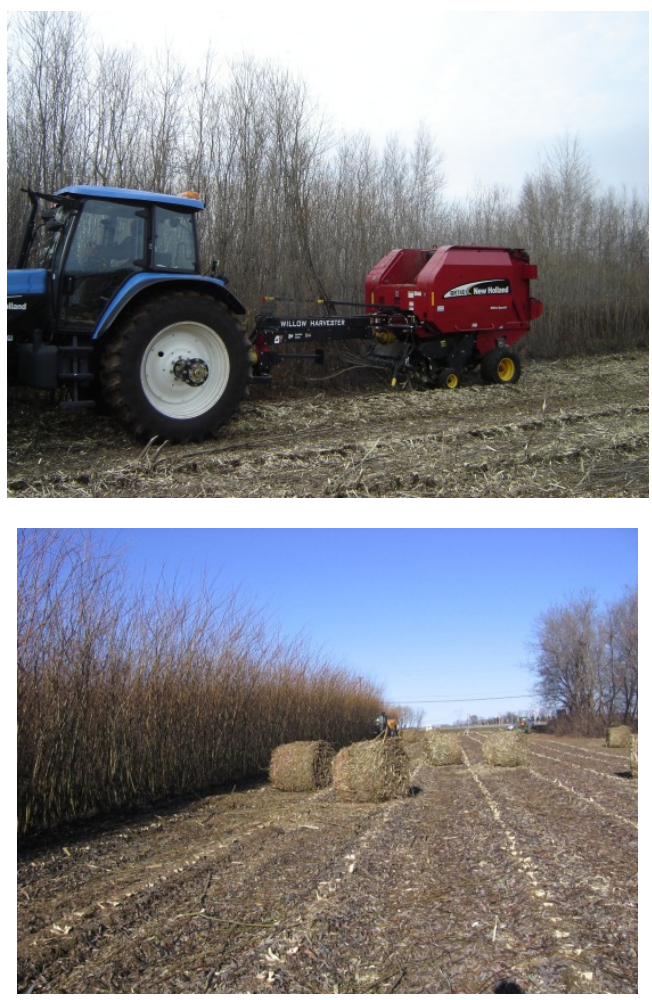

Figure 6. Willow cutter-shredder-baler harvester operating in Quebec

The main advantage is that, since bales can be left to dry before being chipped, the risks linked to handling wet biomass are reduced [75]. In Quebec, willow biomass harvest is usually done in fall after leaf shedding.

As with any other agricultural crop, biomass yield of willow short-rotation coppice depends on many co-occurring factors including cultivar, site, climate and management operations. Soil type, water availability, and pest and weed control also affect yield. Data from existing 
commercial sites in the UK suggest that average yields of around 8-10 odt ha $\mathrm{har}^{-1} \mathrm{yre}^{-1}$ representative of plantations using older cultivars, whereas biomass yields as high as 15-18 odt ha-1 $\mathrm{yr}^{-1}$ can be obtained by using selected genetic material [31]. In other northern European countries, an average annual growth of 15-20 odt $\mathrm{ha}^{-1} \mathrm{yr}^{-1}$ has been observed in early experiments [76], although more recent figures suggest that an average of $10 \mathrm{odt} \mathrm{ha}^{-1} \mathrm{yr}^{-1}$ is more realistic [77]. Experimental yields of short-rotation willow ranging from 24 to 30 oven dry tonnes (odt) ha-1 $\mathrm{yr}^{-1}$ have been measured in the US and Canada [43-44], although typical yields are more often in the range of 10 to $12 \mathrm{odt} \mathrm{ha}^{-1} \mathrm{yr}^{-1}$ [78].

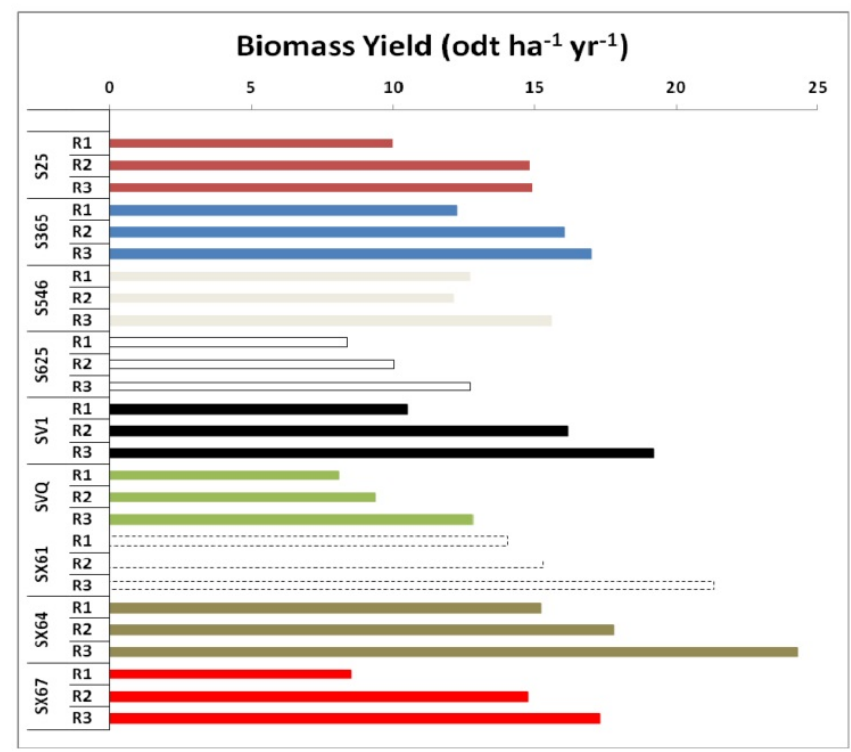

Figure 7. Average biomass yield for nine willow cultivars during three successive rotations (10 years) in the Upper St. Lawrence region (Quebec) on former farmlands. Clones SX64 and SX61 along with some indigenous species (S25, S365, S546) are the most productive and thus are considered to be very suitable for short-rotation forestry in southern Quebec.

Long-term trials show that under southern Quebec's pedoclimatic conditions, short-rotation willow coppice can provide high biomass yields over many years, although results vary according to variety. In one clonal test for instance, at the end of the third (3-years) rotation cycle, the most productive willow cultivars were SX64 (19 Odt ha-1 $\mathrm{yr}^{-1}$ ) and SX61 (17 Odt ha-1 $\mathrm{yr}^{-1}$ ) (Figure 7). Also, indigenous (i.e. North-American) willow cultivars, especially $S$. eriocephala (S25 and S546) and S. discolor (S 365) cultivars, show high biomass potential (13 15 Odt $\left.\mathrm{ha}^{-1} \mathrm{yr}^{-1}\right)$. A scientific follow up of an old willow plantation established in Huntingdon in southern Quebec (Canada), showed that willows were still able to maintain a high level of productivity after five coppicing cycles. Plants can remain vigorous and produce high yields (14 Odt ha- $\mathrm{yr}^{-1}$ ) even after 18 years of cultivation (Table 4). This represents a very important demonstration of the viability of long-term economic exploitation of willows. 


\begin{tabular}{lcc}
\hline & \multicolumn{2}{c}{ Average biomass yield } \\
\cline { 2 - 3 } Rotation & Total $\left(\right.$ Odt ha $\left.^{-1}\right)$ & Annual (Odt ha $\left.{ }^{-1} \mathrm{yr}^{-1}\right)$ \\
\hline $\begin{array}{l}\text { First } \\
(1195-1997)\end{array}$ & 45.3 & 22 \\
$\begin{array}{l}\text { Second } \\
(1998-2001)\end{array}$ & 88.1 & \\
Third & & 17.2 \\
$(2002-2004)$ & 51.7 & 16.9 \\
Fourth & & \\
$(2005-2008)$ & 67.4 & 14 \\
Fifth & & \\
$(2009-2011)$ & 42 & \\
\hline
\end{tabular}

Table 4. Average biomass yield for Salix viminalis L. (clone 5027) achieved during five successive rotations in southern Quebec (Canada)

\section{Perspectives for future research: The use of willows in phytoremediation}

In Canada, it is estimated that millions of hectares of arable land lie uncultivated. These socalled marginal lands tend to be less productive, less accessible, poorly drained, or even contaminated [79]. Willows have been successfully used to capture leached nutrient and heavy metals from soils [54, 59, 80, 81]. The various species of Salix have been shown to establish well on these marginal and contaminated soils, which provides new research opportunities for future applications.

\subsection{Phytoremediation}

The main types of contaminants found in Quebec soils are petroleum products and heavy metals [82]. In many urban areas, past industrial activities have resulted in thousands of contaminated sites that require decontamination prior to any further utilization. Estimates by the province's ministry of environment have shown that, in the region of Montreal alone, there are over 1350 contaminated sites of which only $54 \%$ are in the process of being rehabilitated by traditional methods [83]. Current decontamination methods imply the excavation of the contaminated soils, transport to a landfill treatment facility followed by chemical cleaning, vitrification, incineration or dumping; these steps are extremely expensive [84]. Plant-based in situ decontamination technologies, i.e. phytoremediation, represent a cost-effective alternative [84]. Plants have the capacity to accumulate, translocate, concentrate, or degrade contaminants in their tissues. Phytoremediation takes 
advantage of the microbial communities (bacteria and fungi) present in soils to increase the potential of plants to uptake pollutants from the soil matrix. Willows are among the species most widely used for phytoremediation, given their diversity and tolerance of high levels of contaminants [85]. Also, willows develop an extensive root system that stimulates rich and diverse microbial communities that are involved in the degradation of organic pollutants, These characteristics, combined with exceptionally high biomass production, make them very suitable for phytoremediation [86].

Phytoremediation using willows is becoming an increasingly popular alternative approach to decontamination, and several studies and pilot projects are underway. Willows have been used successfully to treat highly toxic organic contaminants such as PCBs, PAHs, and nitroaromatic explosives [87]. Similarly, willows, in particular S. viminalis and S. miyabeana, have been shown to accumulate $\mathrm{Cd}$ and $\mathrm{Zn}$ in their stems and leaves while sequestering $\mathrm{Cu}, \mathrm{Cr}$, $\mathrm{Ni}$ and $\mathrm{Pb}$ in their roots $[85,88,89,90]$. In previous studies, the efficiency of willows in shortrotation intensive plantation for the elimination of heavy metals contained in wastewater sludge has been investigated $[28,59,90]$. We have also found that willow may be useful for improving sites polluted by mixed organic-inorganic pollution [91] (Figure 8).

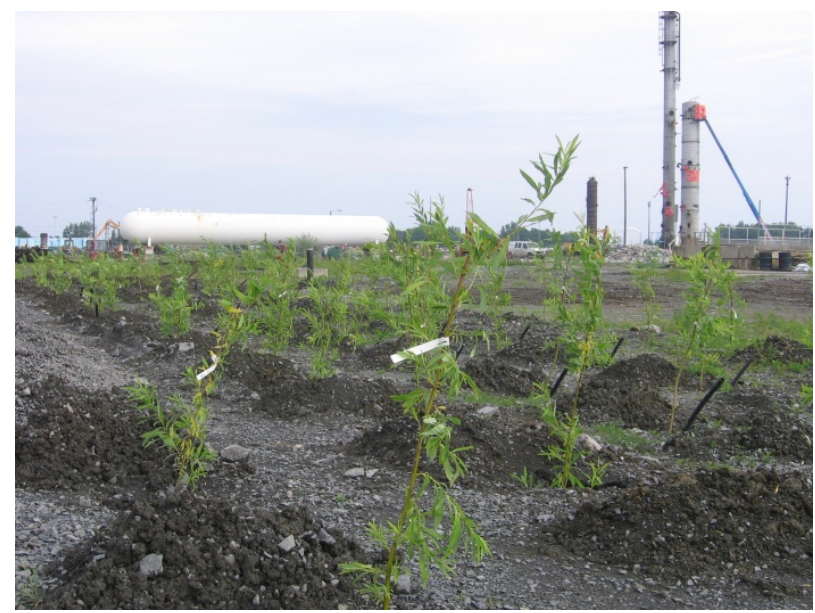

Figure 8. Phytoremediation using willows on a former oil refinery around Montreal

Although the fast-growing perennial habits of short-rotation coppice willow planted at high densities result in a low concentration of metals accumulated in biomass after one year of growth, the high biomass production of Salix spp. over several harvesting cycles (2-3 years) allows them to accumulate large quantities of metals over the long-term, suggesting great potential as a phytoremediation tool.

\subsection{Genetic improvement of willow for phytoremediation}

Historically, most genetic selection to improve willow germplasm has been oriented toward increased capacity for biomass production [92], adapted to temperate climates and resistant 
to pathogens. However, in the context of phytoremediation, the ideal willow genotype must also: i) be adapted to specific pedo-climatic conditions; ii) be fast growing; ii) produce a large root biomass; iv) be resistant to a variety of contaminants; v) have a high concentration factor of contaminants; vi) be easy to establish, maintain and collect. The exceptional diversity of the genus Salix makes it an ideal candidate for breeding programs seeking to develop cultivars more efficient at phytoremediation.

To our knowledge, one of the rare efforts to understand the genetic and genomic bases underlying the potential of willow for phytoremediation is the three-year Genorem project (www.genorem.ca) launched by research teams at the Université de Montréal and McGill University (Project Leaders Dr. B. Franz Lang and Dr. Mohamed Hijri, both of the Université de Montréal) and involving over thirty scientists, students and staff. The project integrates traditional field and molecular biology experiments, employing recently developed life science technologies: genomics, proteomics, metabolomics and bioinformatics. GenoRem's objectives include the development of guidelines for phytoremediation procedures respectful of the environment that will ultimately be useful to both government and corporate sectors. The transcriptomes of 11 willow genotypes will be sequenced, resulting in basic molecular information about the genes activated in willow when in presence of soil contaminants. GenoRem will also investigate the close relationship established between the willow cultivars studied and the associated soil microorganisms. Ultimately, project results will provide willow breeders with gene markers linked with increased phytoremediation potential.

Phytoremediation as a decontamination technology can be applied to large surface areas, causes less environmental disturbances and represents a significantly cheaper approach than traditional methods. However, treatment is lengthy (several years), and the methodologies appropriate for each type of contamination require refinement. While the biomass produced in the context of a phytoremediation project may potentially be contaminated, this does not affect its utilization as a product outside the food chain. Moreover, the highly concentrated ashes resulting from conversion of the biomass to fuel facilitate disposal and treatment of the contaminant, particularly for a large, diluted volume of contaminated soil. Hence the decontamination by means of phytoremediation is a less intensive technique.

\section{Conclusions}

Eastern Canada is one region where willow short-rotation coppice has been the focus of numerous research projects over the last 15-20 years. Most experimental data published during this period concerning Quebec have found a high biomass potential, due to a combination of several factors, including the very high biomass yield of certain willow varieties, favourable pedoclimatic conditions and the very low incidence of severe pests and diseases. These high biomass yields have encouraged some growers to choose willows as an alternative agricultural crop, leading to a dramatic expansion of land devoted to willow short-rotation coppice in the province, especially over the last five years. However, the 
future evolution of this crop's production will most certainly be influenced by the development of an active market for such biomass, which would encourage farmers to grow willow over a much larger surface area. In particular, developments in the technology of feedstock transformation and marketing issues related to product potential both merit further study. The high potential of willow for bioenergy production and environmental applications, including phytoremediation, in the Quebec context has been clearly demonstrated.

\section{Author details}

Werther Guidi, Frédéric E. Pitre and Michel Labrecque

Institut de Recherche en Biologie Végétale (IRBV - Plant Biology Research Institute) - Université de Montréal - The Montreal Botanical Garden, Montréal, Canada

\section{References}

[1] Fargione, J., Hill, J., Tilman, D., Polasky, S., Hawthorne, P., 2008. Land Clearing and the Biofuel Carbon Debt. Science 319, 1235-1238

[2] FAO, 2012. Impacts of Bioenergy on Food Security - Guidance for Assessment and Response at National and Project Levels., Environment and Natural Resources Working Paper, Rome, p. 64.

[3] Tilman, D., Socolow, R., Foley, J.A., Hill, J., Larson, E., Lynd, L., Pacala, S., Reilly, J., Searchinger, T., Somerville, C., Williams, R., 2009. Beneficial Biofuels-The Food, Energy, and Environment Trilemma. Science 325, 270-271.

[4] Nassi o Di Nasso, N., Guidi, W., Ragaglini, G., Tozzini, C., Bonari, E., 2010. Biomass production and energy balance of a twelve-year-old short-rotation coppice poplar stand under different cutting cycles. Global Change Biology Bioenergy 2, 89-97.

[5] Sartori, F., Lal, R., Ebinger, M.H., Parrish, D.J., 2006. Potential Soil Carbon Sequestration and CO2 Offset by Dedicated Energy Crops in the USA. Critical Reviews in Plant Sciences 25, 441-472.

[6] Londo, M., Dekker, J., Ter Kreus, W., 2005. Willow short-rotation coppice for energy and breeding birds: An exploration of potentials in relation to management. Biomass and Bioenergy 28, 281-293.

[7] Bellamy, P.E., Croxton, P.J., Heard, M.S., Hinsley, S.A., Hulmes, L., Hulmes, S., Nuttall, P., Pywell, R.F., Rothery, P., 2009. The impact of growing miscanthus for biomass on farmland bird populations. Biomass and Bioenergy 33, 191-199.

[8] Dickmann, D., 2006. Silviculture and biology of short-rotation woody crops in temperate regions: Then and now. Biomass and Bioenergy 30, 696-705.

[9] Drew, A.P., Zsuffa, L., Mitchell, C.P., 1987. Terminology relating to woody plant biomass and its production. Biomass 12, 79-82.

[10] McAlpine, R., Brown, C., Herrick, A., Ruark, H., 1966. “Silage”sycamore. Forestry Farmer 26 7-16. 
[11] Herrick, A.M., Brown, C.L., 1967. A new concept in cellulose production: silage sycamore. Agricultural Science Review 5, 8-13.

[12] Auclair, D., Bouvarel, L., 1992. Intensive or extensive cultivation of short rotation hybrid poplar coppice on forest land. Bioresource Technology 42, 53-59.

[13] Kenney, W., Sennerby-Forsse, L., Layton, P., 1990a. A review of biomass quality research relevant to the use of poplar and willow for energy conversion. Biomass 21, 163-188.

[14] Sims, R.E.H., Senelwa, K., Maiava, T., Bullock, T., 1999. Eucalyptus for energy in New Zealand-Part II: coppice performance. Biomass and Bioenergy 17, 333-343.

[15] Grünewald, H., Böhm, C., Quinkenstein, A., Grundmann, P., Jörg Eberts, J., von Wühlisch, G., 2009. Robinia pseudoacacia L.: A Lesser Known Tree Species for Biomass Production. Bioenergy Research 2, 123-133.

[16] Rytter, L., Šlapokas, T., Granhall, U., 1989. Woody biomass and litter production of fertilized grey alder plantations on a low-humified peat bog. Forest Ecology and Management 28, 161-176.

[17] Keoleian, G.A., Volk, T.A., 2005. Renewable energy from willow biomass crops: Life cycle energy, environmental and economic performance. Critical Reviews in Plant Sciences 24, 385-406.

[18] Grislis K, Labrecque L., 2009. Proliferating Willow for Biomass. Silviculture Magazine summer 2009, 12-15.

[19] Mosseler, A., 1990. Hybrid performance and species crossability relationships in willows (Salix). Canadian Journal of Botany 68, 2329-2338.

[20] Kenney, W.A., Sennerby-Forsse, L., Layton, P., 1990b. A review of biomass quality research relevant to the use of poplar and willow for energy conversion. Biomass 21, 163-188.

[21] Labrecque, M., Teodorescu, T., Cogliastro, A., Daigle, S., 1993. Growth patterns and biomass productivity of two Salix species grown under short-rotation intensive culture in southern Quebec. Biomass and Bioenergy 4, 419-425.

[22] Lavoie, F., Savoie, P., D'Amours, L., Joannis, H., 2008. Development and field performance of a willow cuttershredder-baler. Applied Engineering in Agriculture 24, 165-172.

[23] Dickmann, D.I., Kuzovkina, J., 2008. Poplars and willows of the world, with emphasis on silviculturally important species. FAO Rome, Italy

[24] Persson, G., 1995. Willow stand evapotranspiration simulated for Swedish soils. Agricultural Water Management 28, 271-293.

[25] Jackson, M., Attwood, P., 1996. Roots of willow (Salix viminalis L) show marked tolerance to oxygen shortage in flooded soils and in solution culture. Plant and Soil 187, 37-45.

[26] Ledin, S., 1996. Willow wood properties, production and economy. Biomass and Bioenergy 11, 75-83. 
[27] Argus, G.W., 1999. Classification of Salix in the New World. Botanical Electronic News 227, http://www.ou.edu/cas/botany-micro/ben227.html.

[28] Labrecque, M., Teodorescu, T., Daigle, S., 1997. Biomass productivity and wood energy of salix species after 2 years growth in SRIC fertilized with wastewater sludge. Biomass and Bioenergy 12, 409-417.

[29] Labrecque, M., Teodorescu, T.I., 2005b. Field performance and biomass production of 12 willow and poplar clones in short-rotation coppice in southern Quebec (Canada). Biomass and Bioenergy 29, 1-9.

[30] Labrecque, M., Teodorescu, T.I., Babeux, P., Cogliastro, A., Daigle, S., 1994. Impact of herbaceous competition and drainage conditions on the early productivity of willows under short-rotation intensive culture. Canadian Journal of Forest Research 24, 493-501.

[31] Defra, 2004. Growing Short Rotation Coppice - Best Practice Guidelines For Applicants to Defra's Energy Crops Scheme. London (UK).

[32] Bergkvist, P., Ledin, S., 1998. Stem biomass yields at different planting designs and spacings in willow coppice systems Biomass and Bioenergy 14, 149-156

[33] Mitchell, C., 1995. New cultural treatments and yield optimization. Biomass and Bioenergy 9, 11-33.

[34] Proe, M., Craig, J., Griffiths, J., 2002. Effects of spacing, species and coppicing on leaf area, light interception and photosynthesis in short rotation forestry Biomass and Bioenergy 23, 315-326

[35] Sennerby-Forsse, L., Ferm, A., Kauppi, A., 1992. Coppicing ability and sustainability. In: Mitchell, C., Ford-Robertson, J., Hinckley, T., Sennerby-Forsse, L. (Eds.), Ecophysiology of short rotation forest crops. Elsevier, London, pp. 146-184.

[36] Willoughby, I., Clay, D.V., 1996. Herbicides for Farm Woodlands and Short Rotation Coppice. London.

[37] Sage, 1999. Weed competition in willow coppice crops: the cause and extent of yield losses. Weed Research 39, 399-411.

[38] Mitchell, C.P., 1992. Ecophysiology of short rotation forest crops. Biomass and Bioenergy 2, 25-37.

[39] Kopp, R.F., White, E.H., Abrahamson, L.P., Nowak, C.A., Zsuffa, L., Burns, K.F., 1993. Willow biomass trials in Central New York State. Biomass and Bioenergy 5, 179-187.

[40] Potter, C.J., 1990. Coppiced trees as energy crops. Final report to ETSU for the DTI on contract ETSU B 1078.

[41] Caslin, B., Finnan, J., McCracken, A.R., 2010. Short Rotation Coppice Willow Best Practice Guidelines.

[42] Hytönen, J., 1995. Ten-year biomass production and stand structure of Salix [']aquatica' energy forest plantation in Southern Finland. Biomass and Bioenergy 8, 63-71.

[43] Labrecque, M., Teodorescu, T., 2003. High biomass yields achieved by Salix clones in SRIC following two 3-years coppice rotations on abandoned farmland in southern Quebec, Canada. Biomass and Bioenergy 25, 135-146. 
[44] Adegbidi, H., Volk, T., White, E., Abrahamson, L., Briggs, R., Bickelaupt, D., 2001. Biomass and nutrient removal by willow clones in experimental bioenergy plantation in New York State. Biomass and Bioenergy 20, 399-411.

[45] Ericsson, T., 1994. Nutrient cycling in energy forest plantations. Biomass and Bioenergy $6,115-121$.

[46] Alriksson, B., Ledin, S., Seeger, P., 1997. Effect of nitrogen fertilization on growth in a Salix viminalis stand using a response surface experimental design. Scandinavian Journal of Forest Research 12, 321-327.

[47] Ledin, S., Willebrand, E., 1996. Handbook on How to Grow Short Rotation Forests. Swedish University of Agricultural Sciences, Department of Short Rotation Forestry, Uppsala.

[48] Buchholz, T., Volk, T., 2011. Improving the Profitability of Willow Crops-Identifying Opportunities with a Crop Budget Model. BioEnergy Research 4, 85-95.

[49] Perttu, K., 1999. Environmental and hygienic aspects of willow coppice in Sweden. Biomass and Bioenergy 16, 291-297.

[50] Martin, P., Stephens, W., 2006. Willow growth in response to nutrients and moisture on a clay landfill cap soil. I: Growth and biomass production. Bioresource Technology 97, 437-448.

[51] Larsson, S., 2003. Short rotation Willow biomass plantation irrigated and fertilized with wastewaters- Results form a 4-year multidisciplinary field project in Sweden, France, Northern Ireland and Greece supported by the EU-FAIR Programme (FAIR5-CT973947) Final Report. Svalov, Sweden.

[52] Jonsson, M., Dimitriou, I., Aronsson, P., Elowson, T., 2006. Treatment of log yard run-off by irrigation of grass and willows. Environmental Pollution 139, 157-166.

[53] Labrecque, M., Teodorescu, T., 2001. Influence of plantation site and wastewater sludge fertilization on the performance and foliar nutrient status of two willow species grown under SRIC in southern Quebec (Canada). Forest Ecology and Management 150, 223239.

[54] Cavanagh, A., Gasser, M.O., Labrecque, M., 2011. Pig slurry as fertilizer on willow plantation. Biomass and Bioenergy 35, 4165-4173.

[55] Hall, R., Allen, S., Rosier, P., Hopkins, R., 1998. Transpiration from coppiced poplar and willow measured using sap-flow methods. Agricultural and Forest Meteorology 90, 275-290.

[56] Guidi, W., Piccioni, E., Bonari, E., 2008. Evapotranspiration and crop coefficient of poplar and willow short-rotation coppice used as vegetation filter Bioresource Technology 99, 4832-4840.

[57] Aronsson, P., Bergstrom, L., 2001. Nitrate leaching from lysimeter- grown short rotation willow coppice in relation to $\mathrm{N}$ - application, irrigation and soil type. Biomass and Bioenergy 21, 155-164. 
[58] Carlander, A., Schönning, C., Stenström, T.A., 2009. Energy forest irrigated with wastewater: a comparative microbial risk assessment. Journal of Water and Health 7 413-433

[59] Labrecque, M., Teodorescu, T., Daigle, S., 1995. Effect of wastewater sludge on growth and heavy metal bioaccumulation of two Salix species. Plant and Soil 171, 303-316.

[60] Bauer, L.S., 1992. Response of the Imported Willow Leaf Beetle to Bacillus thuringiensis var. san diego on Poplar Willow. Journal of Ivertebrate Pathology 59, 330-331.

[61] Sage, R.B., Tucker, K., 1997. Invertebrates in the canopy of willow and poplar short rotation coppices. Aspects of Applied Biology 49, 105-112.

[62] Blackman, R.L., Eastop, V.F., 1994. Aphids on the world's trees:an identification and information guide.

[63] Collins, C.M., Rosado, R.G., Leather, S.R., 2001. The impact of the aphids Tuberolachnus salignus and Pterocomma salicis on willow trees. Ann. Appl. Biol. 138, 133-140.

[64] Aradottir, G.I., Karp, A., Hanley, S., Shield, I., Woodcock, C.M., Dewhirst, S., Collins, C.M., Leather, S., Harrington, R., 2009. Host selection of the giant willow aphid (Tuberolachnus salignus). Proceedings of the 8th International Symposium on Aphids. REDIA, XCII, , 223-225.

[65] Seago, A., Lingafelter, S.W., 2003. Discovery of Crepidodera Bella Parra (Coleoptera: Chrysomelidae: Alticini) in Maryland and redescription. Journal of the New York Entomological Society 111, 51-56.

[66] Pei, M.H., McCracken, A.R. (Eds.), 2005. Rust Diseases of Willow and Poplar CABI Publishing, CAB International Wallingford, Oxfordshire OX10 8DE UK.

[67] Vujanovic, V., Labrecque, M., 2002. Biodiversity of pathogenic mycobiota in Salix bioenergy plantations, Québec. Canadian Plant Disease Survey 82138 -139.

[68] Pei, M., Lindegaard, K., Ruiz, C., Bayon, C., 2008. Rust resistance of some varieties and recently bred genotypes of biomass willows. Biomass and Bioenergy 32, 453-459

[69] Parker, S.R., Pei, M.H., Royle, D.J., Hunter, T., Whelan, M.J., 1995. Epidemiology, population dynamics and management of rust diseases in willow energy plantations. Final Report of Project ETSU B/W6/00214/REP. Energy Technology Support Group, Department of Trade and Industry, UK.

[70] McCracken, A.R., Dawson, W.M., 1997. Growing clonal mixtures of willow to reduce effect of Melampsora epitea var. epitea. European Journal of Forest Pathology 27, 319329.

[71] McCracken, A.R., Dawson, W.M., 2003. Rust disease (Melampsora epited) of willow (Salix spp.) grown as short rotation coppice (SRC) in inter- and intra-species mixtures. Ann. Appl. Biol. 143, 381-393.

[72] Labrecque, M., Teodorescu, T., 2005a. Preliminary evaluation of a living willow (Salix spp.) sound barrier along a highway in Québec, Canada. Journal of Arboriculture 31, 95-98. 
[73] Teodorescu, T.I., Guidi, W., Labrecque, M., 2011. The use of non-dormant rods as planting material: A new approach to establishing willow for environmental applications. Ecological Engineering 37, 1430-1433.

[74] Jirjis, R., 1995. Storage and drying of wood fuel. Biomass and Bioenergy 9, 181-190.

[75] Gigler, J.K., van Loon, W.K.P., van den Berg, J.V., Sonneveld, C., Meerdink, G., 2000. Natural wind drying of willow stems. Biomass and Bioenergy 19, 153-163.

[76] Ceulemans, R., McDonald, A., Pereira, J., 1996. A comparison among eucalyptus, poplar and willow characteristics with particular reference to a coppice, growth-modelling approach. Biomass and Bioenergy 11, 215-231.

[77] Mola-Yudego, B., Aronsson, P., 2008. Yield models for commercial willow biomass plantations in Sweden. Biomass and Bioenergy 32, 829-837.

[78] Volk, T., Kiernan, B., Kopp, R., Abrahamson, L., 2001. First and second-rotation yield of willow clones at two sites in New York State. Proceeding of the 5th Biomass Conference of the Americas., Orlando, FL.

[79] Liu, T.T., McConkey, B.G., Ma, Z.Y., Liu, Z.G., Li, X., Cheng, L.L. 2011. Strengths, Weaknessness, Opportunities and Threats Analysis of Bioenergy Production on Marginal Land. Energy Procedia 5: 2378-2386

[80] Licht, L.A., and Isebrands, J.G. 2005. Linking phytoremediated pollutant removal to biomass economic opportunities. Biomass Bioenergy 28: 203-218.

[81] O'Neill, G.J., and Gordon, A.M. 1994. The nitrogen filtering capability of Carolina poplar in artificial riparian zone. J. Env. Quality 23: 1218-1223.

[82] P. Giasson, A. Jaouich, Giasson P. et A. Jaouich. 1998. La phytorestauration des sols contaminés au Québec. Vecteur environnement 31(4):40-53.

[83] Ministère de l'environnement du Québec. 1994. Dix ans de restauration des terrains contaminés (1983-1993). Gouvernement du Québec, Québec, 30 pp.

[84] McEldowney, S., D. J. Hardman, and S. Waite. 1993. Pollution: Ecology and biotreatment. Longman Scientific \& Technical, Singapore Publishers, Singapore.

[85] Vandecasteele, B., E. Meers, P. Vervaeke, B. D. Vos, P. Quataert, and F. M. G. Tack. 2005. Growth and trace metal accumulation of two Salix clones on sediment-derived soils with increasing contamination levels. Chemosphere 58: 995-1002.

[86] Kuzovkina, Y.A., Volk, T.A. 2009. The characterization of willow (Salix L.) varieties for use in ecological engineering applications: coordination of structure, function and autecology. Ecological Engineering 35, 1178-1189.

[87] Dowling, D. N., and S. L. Doty. 2009. Improving phytoremediation through biotechnology. Current Opinion in Biotechnology 20: 204-206.

[88] Jiménez, E. M., J. M. Peñalosa, R. Manzano, R. O. C. Ruiz, R. Gamarra, and E. Esteban. 2009. Heavy metals distribution in soils surrounding an abandoned mine in NW Madrid (Spain) and their transference to wild flora. Journal of Hazardous Materials 162: 854-859

[89] Harada, E., A. Hokura, S. Takada, K. Baba, Y. Terada, I. Nakai, and K. Yazaki. 2010. Characterization of Cadmium Accumulation in Willow as a Woody Metal Accumulator 
Using Synchrotron Radiation-Based X-Ray Microanalyses. Plant and Cell Physiology 51: 848-853.

[90] Pitre, F. E., Teodorescu T. I., and Labrecque M. 2010. Brownfield Phytoremediation of Heavy Metals using Brassica and Salix supplemented with EDTA: Results of the First Growing Season. Journal of Environmental Science and Engineering 4: 51-59.

[92] Karp, A., Hanley, S. J., Trybush, S. O., Macalpine, W., Pei, M. and Shield, I. (2011), Genetic Improvement of Willow for Bioenergy and Biofuels. Journal of Integrative Plant Biology, 53: 151-165.

[91] Guidi W., Kadri H., Labrecque M. (2012) Establishment techniques to using willow for phytoremediation on a former oil refinery in southern Quebec: achievements and constraints. Chemistry and Ecology 28 (1): 49-64 